Dicle Tıp Dergisi / Dicle Med J (2018) 45 (3) : 309-316

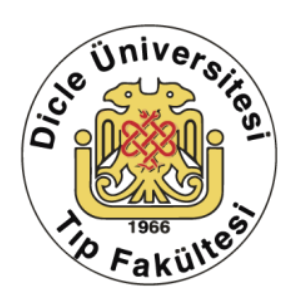

wWW.diclemedj.org

Original Article / Özgün Araştırma

\title{
Association with Platelet Distribution Width and New-Onset Atrial Fibrillation After Coronary Artery Bypass Grafting
}

\author{
Ferhat Özyurtlu1, Gökhan Albayrak² \\ 1 Special Grand Medical Hospital, Clinics of Cardiology. Manisa, Türkiye ORCID: 0000-0001-6814-1254 \\ 2 Special Medical Park Hospital, Clinics of Heart Surgery. İzmir, Türkiye ORCID: 0000-0002-9082-8631
}

Received: 22.03.2018; Revised: 18.05.2018; Accepted: 24.05.2018

\begin{abstract}
Objective: The platelet distribution width (PDW) is one of the parameters of platelet activation. The PDW directly measures the variability in platelet size. However, there has been a limited number of data reported thus far on PDW and postoperative AF in patients undergoing CABG. We aimed to investigate the relationship between the PDW and postoperative AF in patients undergoing CABG.

Methods: 124 consecutive patients with sinus rhythm who had undergone CABG between July 2011 and December 2013 were evaluated. AF was defined as any episode of AF lasting longer than 30 seconds. Complete blood count samples were analyzed according to the results obtained within 48 hours of the preoperative and postoperative period.

Results: The preoperative PDW levels were significantly lower in patients who had developed AF than in the control group ( $56.5 \pm 14.8$ vs. $50.9 \pm 10.0, \mathrm{p}=0.015$ ). There was no correlation between the postoperative PDW levels and AF. The preoperative white blood cell (WBC) and the neutrophil/lymphocyte ratio (NLR) were found to be similar between the two groups, while the postoperative WBC (13.9 \pm 5.7 vs. $10.5 \pm 3.6, p=0.000)$ and NLR $(14.4 \pm 9.4$ vs. 9.0 \pm 8.4 , p: 0. 001) levels were higher in the group of patients who had AF. An NLR of 8.5 predicted post-CABG AF with a sensitivity of $73 \%$ and a specificity of $63 \%$, and a WBC of 10 predicted post-CABG AF with a sensitivity of $77 \%$ and a specificity of $48 \%$.

Conclusion: These results support the hypothesis that preoperative PDW level predicts new-onset AF after CABG, but suggest that other factors are also important.
\end{abstract}

Keywords: Atrial fibrillation, coronary artery bypass surgery, platelet distribution width, white blood cell, neutrophil/lymphocyte ratio.

DOI: $10.5798 /$ dicletip. 457254

Yazışma Adresi / Correspondence: Ferhat Özyurtlu, Special Grand Medical Hospital, Clinics of Cardiology. Güzelyurt mah. Yunusemre, Manisa, Türkiye e-mail:fozyurtlu@yahoo.com 


\section{Koroner Arter Bypass Cerrahisi Sonrası Yeni Gelişen Atrial Fibrilasyon ile Platelet Distribution Width Arasındaki İlişki}

\section{Öz}

Amaç: Platelet distribution width (PDW) trombosit aktivasyon parametrelerinden biridir. PDW trombosit büyüklüğündeki çeşitliliği direkt olarak ölçer. Bununla birlikte şimdiye kadar koroner arter bypass cerrahisi (CABG) yapılan hastalarda postoperatif AF ile PDW ilişkisini inceleyen sınırlı sayıda yayın bulunmaktadır. Biz CABG yapılan hastalarda PDW ile postoperatif AF arasındaki ilişkiyi incelemeyi planladık.

Yöntemler: Haziran 2011 ile Aralık 2013 arasında CABG yapılan 124 ardışık hastayı değerlendirdik. AF, 30 sn den uzun süren AF atakları olarak tanımlanmıştır. Preoperatif ve postoperatif 48 saat içinde tam kan örnekleri incelendi.

Bulgular: Preoperatif PDW değerleri AF grubunda kontrol grubuna göre anlamlı olarak daha düşük bulundu. Preoperatif beyaz kan hücresi (WBC) ve nötrofil lenfosit oranı (NLR) iki grup arasında benzer bulunurken, postoperatif WBC ve NLR değerleri AF' si olan grupta daha yüksek tespit edildi. Postoperatif AF de NLR için 8,5 tahmin değerinin duyarlılığı \%73, özgüllüğü \%63 ve WBC için 10 tahmin değerinin duyarlılığı \%77, özgüllüğü \%48 tespit edildi.

Sonuç: Bu sonuçlar yeni başlangıçlı postCABG AF de PDW değerinin öngördürücülüğü hipotezini desteklememektedir fakat diğer faktörlerin önemli olduğunu göstermektedir.

Anahtar kelimeler: Atrial fibrilasyon, koroner arter bypass cerrahisi, platelet distribution width, beyaz kan hücresi, nötrofil/lenfosit oranı.

\section{INTRODUCTION}

Postoperative atrial fibrillation (AF) can be said to be one of the most prevalent complications of coronary artery by-pass (CABG) operation and it is observed at a rate of $27-40 \%{ }^{1}$. AF developing following a CABG operation increases the cardiovascular morbidity and mortality approximately two-fold ${ }^{2}$. Although most of the cases recover spontaneously, AF must be corrected to avoid complications. PostCABG AF may cause hemodynamic anomalies and ischemic cerebrovascular incidents. In this case, treatments are prolonged, hospitalization is longer and the economic burden increases ${ }^{3,4}$. Thrombocytes are correlated with inflammation and thrombosis, which have effect on the pathogenesis of $\mathrm{AF}^{5}$. The mean platelet volume (MPV), which is indicator of thrombocyte activation also function, is determined to be higher among patients who had AF compared to those who did not ${ }^{6}$. The PDW evaluates the variability in platelet size and is an indicator of platelet activation 7 . PDW is the parameter that is usually used for the differential diagnosis of essential thrombocytosis and reactive thrombocytosis ${ }^{8}$. However, recent research has shown that the PDW has been determined to have a correlation with acute coronary syndromes and to be a parameter of thrombocyte activation ${ }^{9}$. In addition, recent studies have shown that PDW may be a more specific thrombocyte indicator than MPV ${ }^{10}$.

Another finding in the pathophysiology of AF is inflammation ${ }^{11,12}$. Cardiac surgery triggers an inflammatory response including reactions such as release of inflammatory cytokines and complement activation. In recently published studies, a correlation between cellular inflammatory parameters of WBC and NLR with AF that develops after cardiac surgery has been determined 13,14 .

There are no studies that investigate the correlation between post-CABG AF and PDW. Therefore, we planned to inspect the correlation between PDW and other hematological indices with post-CABG AF. 


\section{METHODS}

\section{Study population}

124 patients who had undergone elective CABG operations between July 2011 and December 2013 were accepted in this retrospective study. 66 of these patients are in the group with AF; 58 of these patients are in the control group. Patients who had sinus rhythm on their preoperative electrocardiography and who had undergone isolated CABG operation were included in the study. The exclusion criteria of the study included acute coronary syndrome, severe cardiac valve disease, atrial fibrillation and flutter, renal failure, hypo- and hyperthyroidism, simultaneous cardiac valve operation, active infection, inflammatory disease, and active hematological diseases.

Electrocardiographic follow-up started after the operation and continued for 48-72 hours postoperatively. In addition, 12-lead electrocardiography was recorded daily. The monitor recordings were analysed by the cardiologists. The primary end point was the development of postoperative AF, determined as a rhythm without $\mathrm{P}$ waves, lasting for 30 seconds on Halter follow-up or on a 12-lead electrocardiogram during the first seven-day period after surgery.

\section{Blood samples}

Before the CABG operation was performed, blood was drawn from all of the patients to assess routine laboratory parameters 8 hours postprandial through a vein puncture and the samples were delivered to the laboratory with the purpose of analysis. Samples of blood count were analyzed as per the findings of the preoperative and the postoperative 48th hour. Indices of the platelet in a blood sample collected in tripotassium EDTA $(7.2 \mathrm{mg}$ ) tubes were measured. Samples were analyzed with an automatic blood counter (ADVIA 2120i Haematology System, Siemens Healthcare Diagnostics, Deerfield, Il, USA) utilized for complete blood analysis. High-density lipoprotein (HDL) cholesterol, low-density lipoprotein (LDL) cholesterol, triglyceride and creatinine were measured with the Olympus AU 2700 Plus Chemistry-Immuno Analyzer (USA).

\section{Echocardiography}

The patients received a transthoracic echocardiography performed using a system Philips HD11 XE with a $2.5 \mathrm{MHz}$ phased-array transducer (Philips Medical Systems, Andover, MA, USA). The recordings were performed while the patients were in the left lateral decubitus position. Evaluation of the left atrium (LA) and interventricular septum (IVS) were acquired from the parasternal long axis view. The modified Simpson's rule was used for the left ventricular ejection fraction (LVEF) measurement.

\section{Statistical analysis}

The SPSS 21.0 program was utilized for the analysis. Mean, standard deviation, median, min-max, ratio and frequency values were applied for the descriptive statistics of the data. Variables' distribution was checked using the Kolmogorov Smirnov test. For the analysis of the quantitative data the independent sampling $T$ test and the Mann-Whitney $U$ test were applied and for the analysis of the qualitative data the chi-square test was applied. The matched sampling test and the Wilcoxon test were used for repeated measurements. All of the variables that were statistically significant in the univariate model were then input into a multivariate model with backward elimination $(\mathrm{P}<0.05$ for retention). The cut-off values for WBC and NLR for predicting the post-CABG AF with corresponding specificity and sensitivity were determined by receiver operator characteristic (ROC) curve analysis. In the study the differences were considered significant at a $p$ value of $<0.05$. 


\section{Ethical considerations}

We conducted this study in accordance with the Declaration of Helsinki and it was approved by the institutional ethics committee.

\section{RESULTS}

274 patients fulfilled the defined criteria. 66 (24\%) of these patients were determined to have postoperative AF. There are 274 patients who are appropriate for the defined exclusion and inclusion criterion among the patients who underwent elective CABG operation between 2011 and 2013. Post-op AF developed in the 66 of these patients. Also 58 of these patients were included in the control group. The clinical characteristics, echocardiographic and biochemical parameters of the patients in both groups are shown in Table I. There was no significant difference between the group of patients who had AF and the group of patients who did not have AF with regard to diabetes mellitus, smoking, triglyceride, erythrocyte suspension and fresh frozen plasma administration. On the other hand, the mean age $(64.2 \pm 9.4$ vs. $58 \pm 8.3)$ and the number of female patients $(22.7 \%$ vs. $8.6 \%)$ in the group with AF were found significant than than those in the control group. Hypertension (HT), hyperlipidemia (HL), by-pass duration, cross clamp duration, LDL cholesterol , creatinine , LA and IVS were found to be higher in the group with AF, and HDL cholesterol and LVEF were found to be lower.

Hematological parameters are given in Table II. Also,the preoperative white blood cell (WBC), neutrophil/lymphocyte ratio (NLR), MPV, platelet/lymphocyte ratio (PLR), monocyte, plateletcrit and hemoglobin levels were found to be similar between the two groups. PDW ( $56.5 \pm 14.8$ vs. $50.9 \pm 10.0, p=0.015)$ was higher in the group that did not developed AF, while the red cell distribution width (RDW) levels of the group with AF were significantly higher. The postoperative PDW, PLR, monocyte, plateletcrit and hemoglobin values were resembling between the two groups, while
WBC, NLR, MPV and RDW values of the group with $\mathrm{AF}$ were higher.

Table I: Baseline demographic and clinical characteristics of the study population

\begin{tabular}{|l|l|l|l|}
\hline Variables & AF Group & $\begin{array}{l}\text { Control } \\
\text { Group }\end{array}$ & $\begin{array}{l}\text { P } \\
\text { Value }\end{array}$ \\
\hline Age (years) & $64.2 \pm 9.4$ & $58.0 \pm 8.3$ & 0.000 \\
\hline Gender(male/female) & $51 / 15$ & $53 / 5$ & 0.033 \\
\hline Diabetes Mellitus, n (\%) & $34(51.5)$ & $20(34.5)$ & 0.056 \\
\hline Hypertension, n (\%) & $58(87.9)$ & $22(37.9)$ & 0.000 \\
\hline Hyperlipidemia, n (\%) & $31(47)$ & $17(29,3)$ & 0.044 \\
\hline Smoking, n (\%) & $37(56.1)$ & $33(56.9)$ & 0.925 \\
\hline By-Pass time (min) & $99.5 \pm 33.9$ & $87.4 \pm 27.5$ & 0.032 \\
\hline Cross-Clamp time (min) & $57.9 \pm 24.2$ & $49.4 \pm 15.8$ & 0.024 \\
\hline HDL-C (mg/dl) & $36.5 \pm 9.8$ & $41.9 \pm 8.3$ & 0.001 \\
\hline LDL-C (mg/dl) & $129.5 \pm 35.4$ & $116.1 \pm 36.1$ & 0.040 \\
\hline Triglycerides (mg/dl) & $166.8 \pm 63.6$ & $158.5 \pm 86.9$ & 0.546 \\
\hline Creatinine (mg/dl) & $1.1 \pm 0.4$ & $1.0 \pm 0.3$ & 0.008 \\
\hline EF(\%) & $49.5 \pm 10.8$ & $55 \pm 7.9$ & 0.003 \\
\hline Left atrium (mm) & $42.8 \pm 7.9$ & $38 \pm 3.1$ & 0.000 \\
\hline $\begin{array}{l}\text { Interventricular septum } \\
\text { (mm) }\end{array}$ & $12.5 \pm 1.1$ & $11.5 \pm 0.7$ & 0.009 \\
\hline RBC units transfused & $4.5 \pm 2.7$ & $3.2 \pm 1.6$ & 0.054 \\
\hline $\begin{array}{l}\text { Fresh-frozen plasma } \\
\text { units transfused }\end{array}$ & $3.1 \pm 1.7$ & $2.6 \pm 1.5$ & 0.084 \\
\hline
\end{tabular}

HDL-C:high density lipoprotein cholesterol. LDL-C:low density lipoprotein cholesterol. EF: ejection fraction. RBC:red blood cell T-test, mann-whitney u test, chi-square test. Data are shown as mean $\pm \mathrm{SD}$, median [interquartile range].

Table II: Comparison of hematologic parameters in the study population

\begin{tabular}{|l|l|l|l|l|}
\hline \multicolumn{2}{|l|}{ Variables } & AF Group & $\begin{array}{l}\text { Control } \\
\text { Group }\end{array}$ & P Value \\
\hline \multirow{3}{*}{ WBC $\left(\times 10^{9} / \mathrm{L}\right)$} & preop & $8.3 \pm 2.7$ & $8.7 \pm 2.0$ & 0.392 \\
\cline { 2 - 5 } & postop & $13.9 \pm 5.7$ & $10.5 \pm 3.6$ & 0.000 \\
\hline \multirow{3}{*}{ MPV (fL) } & preop & $8.4 \pm 0.9$ & $8.5 \pm 1.6$ & 0.598 \\
\cline { 2 - 5 } & postop & $9.0 \pm 1.1$ & $8.6 \pm 1.2$ & 0.034 \\
\hline \multirow{3}{*}{ RDW (\%) } & preop & $16.2 \pm 8.2$ & $16.0 \pm 12.2$ & 0.008 \\
\cline { 2 - 5 } & postop & $16.0 \pm 6.0$ & $14.3 \pm 1.1$ & 0.000 \\
\hline \multirow{3}{*}{ PDW (fL) } & preop & $50.9 \pm 10.0$ & $56.5 \pm 14.8$ & 0.015 \\
\cline { 2 - 5 } & postop & $56.9 \pm 8.4$ & $55.9 \pm 6.3$ & 0.427 \\
\hline
\end{tabular}




\begin{tabular}{|l|l|l|l|l|}
\hline \multirow{2}{*}{$\begin{array}{l}\text { Monocyte } \\
\text { (x109/L) }\end{array}$} & preop & $0.5 \pm 0.2$ & $0.6 \pm 0.7$ & 0.272 \\
\cline { 2 - 5 } & postop & $0.7 \pm 0.3$ & $1.9 \pm 9.4$ & 0.604 \\
\hline $\begin{array}{l}\text { Hemoglobin } \\
\text { (g/dL) }\end{array}$ & preop & $13.1 \pm 2.1$ & $13.7 \pm 1.6$ & 0.128 \\
\cline { 2 - 5 } & postop & $11.1 \pm 1.7$ & $11.2 \pm 1.5$ & 0.638 \\
\hline \multirow{2}{*}{$\begin{array}{l}\text { Platelet } \\
\text { (x109/L) }\end{array}$} & preop & $251.7 \pm 83.6$ & $237.3 \pm 89.1$ & 0.356 \\
\cline { 2 - 5 } & postop & $167.3 \pm 64.0$ & $178.4 \pm 72.5$ & 0.368 \\
\hline \multirow{3}{*}{ PCT (\%) } & preop & $0.2 \pm 0.1$ & $0.2 \pm 0.1$ & 0.697 \\
\cline { 2 - 5 } NLR & postop & $0.2 \pm 0.1$ & $0.2 \pm 0.1$ & 0.412 \\
\hline \multirow{3}{*}{ PLR } & preop & $3.1 \pm 1.8$ & $3.1 \pm 1.7$ & 0.958 \\
\cline { 2 - 5 } & postop & $14.4 \pm 9.4$ & $9.0 \pm 8.4$ & 0.001 \\
\cline { 2 - 5 } & preop & $141.1 \pm 73.2$ & $126.3 \pm 63.9$ & 0.397 \\
\hline
\end{tabular}

WBC:white blood cell. MPV:mean platelet volume. RDW:red cell distribution width. PDW:platelet distribution width.

PCT:plateletcrit. NLR:neutrophil lemphocyte ratio. PLR:platelet lymphocyte ratio.

T-test, mann-whitney u test, Wilcoxon test. Data are shown as mean $\pm \mathrm{SD}$, median [interquartile range].
Gender, age, and the WBC, MPV, NLR values were found to be significantly effective $(p<0.05)$ for the differentiation of the group with $\mathrm{AF}$ and the control group with the univariate logistic regression analysis. Age (OR $=1.08$ 95\% CI: $1.04-1.13 \mathrm{p}<0.001$ ) and $\mathrm{WBC}$ $(\mathrm{OR}=1.2195 \%$ CI 1.09-1.35 $\mathrm{p}<0.001)$ were determined as independent risk factors for for post CABG AF development with the multivariable logistic regression analysis.

A NLR of 8.5 predicted post-CABG AF with a sensitivity of $72.7 \%$ and a specificity of $63.0 \%$ (ROC AUC 0.707, 95\% CI 0.615-0.800, p<0.001) (Figure 1), and a WBC of 10 predicted postCABG AF with a specificity of $48.0 \%$ and a sensitivity of $77.0 \%$ (ROC AUC $0.696,95 \%$ CI 0.604-0.787, $\mathrm{p}<0.001$ ) (Figure 1).

Table III: Univariate and multivariate logistic regression analyses of independent parameter
\begin{tabular}{|l|l|l|l|l|}
\hline \multirow{2}{*}{ Variables } & \multicolumn{2}{|l|}{ Univariate } & \multicolumn{2}{l}{ Multivariate } \\
\cline { 2 - 6 } & Odds ratio (\%95 CI) & P value & Odds ratio (\%95 CI) & P value \\
\hline Gender & $3.12(1.06-9.21)$ & 0.040 & & \\
\hline Age (years) & $1.08(1.04-1.13)$ & $<0.001$ & $1.08(1.03-1.138)$ & 0.001 \\
\hline WBC & $1.21(1.09-1.35)$ & $<0.001$ & $1.22(1.09-1.35)$ & 0.001 \\
\hline Platelet & $1.40(1.02-1.93)$ & 0.037 & & \\
\hline PDW & $1.00(0.99-1.00)$ & 0.366 & & \\
\hline Monocyte & $0.94(0.76-1.16)$ & 0.581 & & \\
\hline Hemoglobin & $0.95(0.76-1.18)$ & 0.636 & & \\
\hline PCT & $0.06(0.01-45.47)$ & 0.409 & & \\
\hline NLR & $1.08(1.03-1.14)$ & 0.003 & & \\
\hline PLR & $1.00(1.00-1.01)$ & 0.112 & & \\
\hline
\end{tabular}

\section{DISCUSSION}

We found that preoperative PDW levels in the group that developed post-CABG AF to be significantly lower than in the control group. AF may be seen as a common complication after CABG operation. Research has revealed a correlation between increased thrombogenic activity and inflammation and the development of $\mathrm{AF}^{15,16}$ The PDW evaluates the variability in platelet size also an indicator of platelet activation ${ }^{7}$. Vagdatli et al. ${ }^{10}$ have reported that PDW seems to be a more specific marker of platelet activation than MPV, as there is no 
platelet swelling. The increased numbers and size of platelets in pseudopodia differ in size, possibly influencing the PDW. In the study of Khandekar et al., PDW was determined to be significantly higher in patients with acute coronary syndrome ${ }^{17}$. However, there are studies that did not find a significant relationship with PDW, in addition to studies that have determined a significant relation with PDW as our study. In another study, PDW was determined to be significantly lower among the patients who had MPV with aortic aneurysm than in the control group ${ }^{18}$. In our study, investigating the correlation between coronary artery disease incidence and hematological indices, no significant relationship was detected with $\mathrm{PDW}^{19}$. In the study investigating the correlation of thrombocyte indices in elderly patients and the annual all-cause mortality, no significant relationship with PDW was determined ${ }^{20}$. Furthermore, some authors have reported that thrombocyte indices may be a potential marker of thrombocyte activation ${ }^{10}$, while others have reported the opposite ${ }^{21}$. Santimone et al. determined a significant inverse relationship between WBC and PDW in the study they published ${ }^{22}$. There are also other studies revealing the possible correlation between low PDW and inflammation ${ }^{18}$. As in other studies revealing the correlation between low PDW and inflammation, the PDW levels were determined to be low, while inflammation markers were found to be higher as in this study, and the significant relationship with post-CABG AF was determined. There are contradictory findings about the relationship between PDW with thrombogenic activity and atherosclerosis as shown by the aforementioned studies.

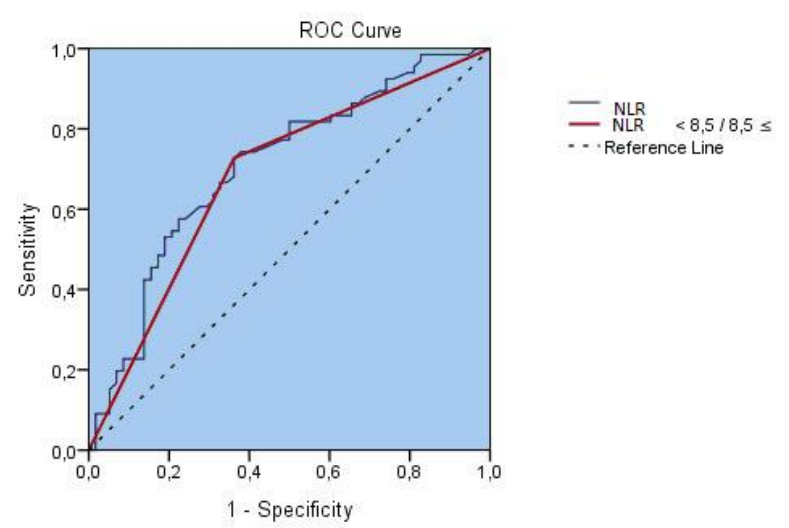

Figure 1. Receiver-operating characteristic (ROC) curve analysis for prediction of postoperative atrial fibrillation (AF) by WBC (white blood cell) and NLR (neutrophil/lymphocyte ratio).

Inflammation is an important reason in development of post-CABG AF. Some studies showing the correlation between inflammatory parameters such as $\mathrm{CRP}^{23}, \mathrm{WBC}^{24}$ and $\mathrm{NLR}^{14}$ and the development of post-CABG AF. We found WBC and NLR values to be significantly higher in the group that had developed postCABG AF than in the control group. Also, in the multivariate logistic regression analysis, we found that age and WBC were independent predictors for the development of post-CABG $A F$. The increase in postoperative WBC may be a result of the neuroendocrine stress response, direct tissue damage, endotoxin release, protamine administration and inflammatory reaction. Unlike the study of Fontes et al. ${ }^{13}$, in our study, we found no relationship between the preoperative $\mathrm{WBC}$ and post-CABG $\mathrm{AF}$ 
development. However, we found that postoperative $\mathrm{WBC}$ is an independent predictor of post-CABG AF development. It has been reported that post-CABG AF develops less commonly if glucocorticoids are administered during cardio-pulmonary bypass and postoperatively after off-pump surgery, which is thought to cause less postoperative inflammation ${ }^{25}$. Supporting these findings, in our study too, the postoperative inflammation parameters, the postoperative WBC and NLR, were found to be higher in the post-CABG AF patients who had longer by-pass and cross clamp durations.

\section{Study Limitations}

Our study was limited by the inherent imperfections of retrospective observational studies. Another limitation was the small sample size. Yet another restriction was that CRP was not evaluated due to the retrospective nature of the study in which we evaluated inflammatory parameters in the development of post-CABG AF.

\section{CONCLUSION}

In this study, the evaluation of the relation between PDW and the development of postCABG $\mathrm{AF}$; and a negative relationship was determined between the two markers. Although we found a negative relation between the PDW and post-CABG AF, further wideranged studies should be conducted, since there are contradictory findings in the literature about the correlation between PDW, atherosclerosis and thrombogenic activity. However, we have shown that the postoperative $\mathrm{WBC}$ is an independent predictor of post-CABG AF. We investigate these parameters in this study are routinely checked parameters and they may be beneficial for the assessment of post-CABG AF without additional costs.
Declaration of Conflicting Interests: The authors declare that they have no conflict of interest.

Financial Disclosure: No financial support was received.

\section{REFERENCES}

1. Mathew JP, Fontes ML, Tudor IC, et al: A multicenter risk index for atrial fibrillation after cardiac surgery. JAMA 2004; 291: 1720-9.

2. Ahlsson A, Bodin L, Fengsrud E, Englund A: Patients with postoperative atrial fibrillation have a doubled cardiovascular mortality. Scand Cardiovasc J 2009; 12: 1-7.

3. Zangrillo A, Landoni G, Sparicio D, et al. Predictors of atrial fibrillation after offpump coronary artery bypass graft surgery. J Cardiothorac Vasc Anesth. 2004 Dec; 18: 704-8.

4. Kollar A, Lick SD, Vasquez KN, Conti VR. Relationship of atrial fibrillation and stroke after coronary artery bypass graft surgery : when is anticoagulation indicated? Ann Thorac Surg. 2006 Aug; 82: 515-23.

5. Gasparyan AY, Ayvazyan L, Mikhailidis DP, Kitas GD. Mean platelet volume: A link Between thrombosis and inflammation? Curr Pharm Des 2011; 17: 47-58.

6. Choudhury A, Chung I, Blann AD, Lip GY. Platelet surface CD62P and CD63, mean platelet volume, and soluble/platelet P-selectin as indexes of platelet function in atrial fibrillation: a comparison of "healthy control subjects" and "disease control subjects" in sinüs rhythm. J Am Coll Cardiol 2007; 49: 1957-64.

7. De Luca G, Venegoni L, Iorio S, Secco GG, Cassetti E, Verdoia M, Schaffer A, Coppo L, Bellomo G, Marino P; Novara Atherosclerosis Study Group. Platelet distribution width and the extent of coronary artery disease: Results from a large prospective study. Platelets 2010; 21: 508-14.

8. Herve P, Humbert M, Sitbon O, et al. Pathobiology of pulmonary hypertension: the role of platelets and thrombosis. Clin Chest Med 22: 451-8.

9. M M Khandekar, A S Khurana, S D Deshmukh, et al. Platelet volume indices in patients with coronary artery disease and acute myocardial infarction: an Indian scenario. J Clin Pathol. 2006 February; 59: 1469. doi: $10.1136 /$ jcp.2004.025387

10. Vagdatli E, Gounari E, Lazaridou E, et al. Platelet distribution width: a simple, practical and specific marker of activation of coagulation. Hippokratia 2010; 14: 28-32. 
11. Chung MK, Martin DO, Sprecher D, et al. C-reactive protein elevation in patients with atrial arrhythmias: inflammatory mechanisms and persistence of atrial fibrillation. Circulation 2001; 104: 2886-91.

12. Köroğlu S, Tuncer C, Acar G, et al. Relation of inflammatory and oxidative markers to the occurrence and recurrence of persistent atrial fibrillation. Turk Kardiyol Dern Ars. 2012 Oct; 40 : 499-504. doi: 10.5543/tkda.2012.64160.

13. Fontes ML, Amar D, Kulak A, et al. Increased preoperative white blood cell count predicts postoperative atrial fibrillation after coronary artery bypass surgery. J Cardiothorac Vasc Anesth. 2009 Aug; 23: 484-7. doi: 10.1053/j.jvca.2009.01.030.

14. Gibson PH, Cuthbertson BH, Croal BL, et al. Usefulness of neutrophil/lymphocyte ratio as predictor of new-onset atrial fibrillation after coronary artery bypass grafting. Am J Cardiol. 2010 Jan 15; 105: 186-91. doi: 10.1016/j.amjcard.2009.09.007.

15. Boos CJ, Anderson RA, Lip GY. Is atrial fibrillation an inflammatory disorder? Eur Heart J 2006; 27: 136-49.

16. Sohara H, Amitani S, Kurose M, Miyahara K. Atrial fibrillation activates platelets and coagulation in a timedependent manner: A study in patients with paroxysmal atrial fibrillation. J Am Coll Cardiol 1997; 29: 106-12.

17. M M Khandekar, A S Khurana, S D Deshmukh, et al. Platelet volume indices in patients with coronary artery disease and acute myocardial infarction: an Indian scenario. J Clin Pathol. 2006 February; 59: 1469. doi: 10.1136/jcp.2004.025387

18. Ihara A, Matsumoto K, Kawamoto T, et al. Evaluation of platelet indexes in patients with aortic aneurysm. Pathophysiol Haemost Thromb 2005; 34: $269 \mathrm{e} 73$.
19. U Turk, I Tengiz, E Ozpelit, et al. The relationship between platelet indices and clinical features of coronary artery disease. Kardiologia Polska 2013; 71, 11: 1129-34; DOI: 10.5603/KP.2013.0293.

20. D Calvo, B Delgado, S González, et al. Platelet distribution width is associated with 1-year all-cause mortality in the elderly population. Journal of Clinical Gerontology \& Geriatrics 4 (2013) 12e16.

21. Beyan C, Kaptan K, Ifran A. Platelet count, mean platelet volume, platelet distribution width, and plateletcrit do not correlate with optical platelet aggregation responses in healthy volunteers. J Thromb Thrombolysis 2006; 22: 161e4.

22. Santimone I, Di Castelnuovo A, De Curtis A, et al. White blood cell count, sex and age are major determinants of heterogeneity of platelet indices in an adult general population: results from the MOLI-SANI project. Haematologica 2011; 96: 1180e8.

23. Lo B, Fijnheer R, Nierich AP, et al. C-reactive protein is a risk indicator for atrial fibrillation after myocardial revascularization. Ann Thorac Surg 2005; 79: 1530-5.

24. Fontes ML, Amar D, Kulak A, et al. Increased preoperative white blood cell count predicts postoperative atrial fibrillation after coronary artery bypass surgery. J Cardiothorac Vasc Anesth. 2009 Aug; 23: 484-7. doi: 10.1053/j.jvca.2009.01.030.

25. A Anselmi, G Possati, M Gaudino. Postoperative Inflammatory Reaction and Atrial Fibrillation: Simple Correlation or Causation?. Ann Thorac Surg 2009; 88: $326-33$. 